\title{
The Effect of Phospholipase C on Human
}

\section{Blood Platelets}

\author{
Anne-Brit Otnaess and Turm Holm \\ From the Institute of Medical Biology, University of Troms $\varnothing, 9000$ Troms $\varnothing$, Norway
}

\begin{abstract}
A B S T R A C T The effect of phospholipase C (EC 3.1.4.3) on human blood platelets has been studied. Phospholipase $\mathrm{C}$ from Bacillus cereus was purified to homogeneity as judged by analytical and sodium dodecyl sulphate disc gel electrophoresis and by immunoelectrophoresis. Human platelets isolated from platelet-rich plasma by gel filtration or by centrifugation and washing were incubated with phospholipase $\mathrm{C}$.

A loss of $20-45 \%$ of the total platelet phospholipid was observed, whereas $88 \%$ was hydrolyzed when platelet homogenates were submitted to identical enzyme treatment. Intact platelets lost 50-75\% phosphatidylethanolamine, $20-50 \%$ phosphatidylcholine, and $20-25 \%$ phosphatidylserine. Sphingomyelin was not a substrate for the enzyme under the conditions used. The platelets contained no detectable endogenous phospholipase C activity.

The loss of phospholipid was not accompanied by aggregation of the platelets, nor did the platelets lose their ability to aggregate with ADP or thrombin. Total platelet factor 3 releasable by freezing and thawing was reduced. Measurements of releasable platelet factor 4 and the efflux of serotonin showed that no release reaction was triggered even when up to $45 \%$ of the total phospholipid in the platelets was hydrolyzed. When sphingomyelinase was added together with, before, or after phospholipase C, aggregation occurred. Sphingomyelinase alone gave no aggregation. The gel-filtered platelets also aggregated upon addition of purified phospholipase $\mathrm{C}$ from Clostridium perfringens. The distribution of phospholipids in the platelet membrane is discussed.
\end{abstract}

\section{INTRODUCTION}

Recently, Schick and Yu (1) reported that a commercially available preparation of phospholipase $C$ (EC

Received for publication 29 September 1975 and in revised form 26 January 1976.
3.1.4.3) (PLC) ${ }^{1}$ from Clostridium perfringens caused the release reaction of platelets, together with the hydrolysis of platelet phospholipids, which were situated at or near the active site or "receptor" on the platelet surface and functioned as the modulator for the release reaction. Chap and Douste-Blazy (2) found essentially the same in similar experiments using the $C$. perfringens phospholipase $C$ from another commercial source. However, neither of these enzyme preparations was pure; hence it was of interest to examine the effects of a highly purified, electrophoretically homogeneous PLC from $B$. cereus. The latter enzyme differs from the $C$. perfringens enzyme in that it does not attack sphingomyelin under the conditions used here.

\section{METHODS}

Materials. ADP, sodium salt, albumin, and apyrase (Grade A) were obtained from Sigma Chemical Co., St. Louis, Mo. Bovine thrombin was obtained from HoffmanLa Roche, Basel, Switzerland. Human fibrinogen (90\% clottable) from Kabi, Stockholm, Sweden, was dissolved in $0.15 \mathrm{M}$ sodium chloride. Casein was obtained from Merck AG, Inc., Darmstadt, Germany. Sepharose 2B was obtained from Pharmacia AB, Uppsala, Sweden. PLC (C. perfringens) was purified and characterized as described by Möllby and Wadstr $\not \mathrm{m}$ (3). Sphingomyelin phosphodiesterase (SMase) (Staphylococcus aureus) (EC 3.1.4.12) was purified and characterized as described by Wadstr $\varnothing \mathrm{m}$ and Möllby (4, 5 ) and Möllby and Wadstr $\varnothing m$ (6). Both enzymes were kindly donated by Dr. Roland Möllby, Karolinska Institutet, Stockholm, Sweden.

Preparation of platelet suspension. Human platelets were prepared from blood drawn from fasting donors into plastic equipment containing 0.1 vol of acid citrate-dextrose anticoagulant (7). Platelet-rich plasma was obtained by centrifugation at $120 \mathrm{~g}$ for $15 \mathrm{~min}$ at $22^{\circ} \mathrm{C}$ in a Sorvall

${ }^{1}$ Abbreviations used in this paper: 5HT, serotonin; PC, phosphatidylcholine; $\mathrm{PE}$, phosphatidylehanolamine; $\mathrm{PF}-3$, platelet factor 3 ; PF-4, platelet factor 4; PLC, phospholipase C (EC 3.1.4.3) ; PS, phosphatidylserine; SM, sphingomyelin; SMase, sphingomyelin phosphodiesterase (EC 3.1.4.12). 
GLC-1 centrifuge (Dupont Instruments, Sorvall Operations, Newtown, Conn.).

The platelets were separated from the plasma proteins as described (8) by the gel filtration method of Tangen and Berman (9). The platelets were eluted with a solution containing 1 part $0.14 \mathrm{M} \mathrm{NaCl}$ and 9 parts $0.145 \mathrm{M}$ Tris$\mathrm{HCl}, \mathrm{pH} 7.6$, with $0.1 \%$ glucose, $50 \mu \mathrm{M} \mathrm{CaCl}, 0.98 \mathrm{mM}$ $\mathrm{MgCl}_{2}, 5.4 \mathrm{mM} \mathrm{KCl}, 1.5 \mathrm{~g} / 100 \mathrm{ml}$ of albumin, and $5 \mathrm{mg} /$ $100 \mathrm{ml}$ of apyrase. The albumin preparation contained less than $0.3 \%$ phospholipid. Platelets were also prepared by washing and centrifugation as described by Mustard et al. (10). Platelet-poor plasma was obtained by centrifugation at $12,000 \mathrm{~g}$ for $10 \mathrm{~min}$ at $4^{\circ} \mathrm{C}$. Platelets were counted in a Thrombocounter (Coulter Electronics Ltd., Harpenden, England).

$P L C$. The enzyme (PLC) was purified from the culture filtrate of $B$. cereus ATCC 10987 AB-1 (11) by affinity chromatography as described earlier (12). The enzyme preparations were homogeneous in analytical disc electrophoresis and sodium dodecyl sulfate electrophoresis. When injected into goats and rabbits, they gave rise to antisera which were monospecific in immunoelectrophoresis against purified PLC as well as against a concentrate of crude bacterial culture supernate. ${ }^{2}$ The enzyme had no proteolytic activity on a casein substrate and less than $2 \%$ hemolytic activity when $10 \mu \mathrm{g}$ PLC was incubated for $1 \mathrm{~h}$ at $37^{\circ} \mathrm{C}$ with a $2.5 \%$ suspension of washed human erythrocytes. The concentration of the stock solution of enzyme in Veronalbuffered saline (13) containing $1 \mathrm{mM} \mathrm{ZnCl}_{2}$ was $0.3 \mathrm{mg} / \mathrm{ml}$. Under these conditions the enzyme is stable for at least 12 mo at $-20^{\circ} \mathrm{C}$.

Incubation conditions. Gel-filtered platelets $\left(1.8-3.2 \times 10^{8}\right.$ platelets $/ \mathrm{ml}$ ) were incubated in nylon centrifuge tubes for 20 min at $37^{\circ} \mathrm{C}$ with PLC or buffer. The final concentration of PLC was 2.5-22.7 $\mu \mathrm{g}$ PLC/10 $10^{8}$ platelets (5.9-37.5 $\mu \mathrm{g}$ $\mathrm{PLC} / \mathrm{ml})$. Before and at the end of the incubation period, samples were withdrawn for (a) aggregation measurement, (b) testing of platelet factor $3(\mathrm{PF}-3)$ activity, and (c) measurement of platelet factor 4 ( $P F-4)$. The remaining incubation mixture was centrifuged $(40,000 \mathrm{~g}$ for $30 \mathrm{~min}$ at $4^{\circ} \mathrm{C}$ ), and residual lipid phosphorus in the platelets was examined.

Extractions of lipids. The centrifuged platelets were suspended in $1 \mathrm{ml} 0.15 \mathrm{M}$ saline, and lipids were extracted with methanol and chloroform $(2: 1)$ according to the method of Vikrot (14), with $5 \mathrm{ml}$ of saturated $\mathrm{NaCl}$ in the procedure instead of $\mathrm{CaCl}_{2}$ (15). In three experiments this extraction method was compared with that of Folch et al. (16), as modified by Marcus et al. (17), except that $\mathrm{NaCl}$ was used instead of $\mathrm{CaCl}_{2}$. No significant differences were found.

Phospholipid fractionation. The phospholipid distribution was determined by thin-layer chromatography with $0.5 \mathrm{~mm}$ silica gel $\mathrm{H}$ (Merck) on glass plates measuring $20 \times 6 \mathrm{~cm}$ or $20 \times 20 \mathrm{~cm}$. The plates were activated at $120^{\circ} \mathrm{C}$ for $80 \mathrm{~min}$ before use, and the solvent system was chloroform: methanol: glacial acetic acid: water, $65: 25: 8: 4$ by vol (18). The chromatography was done in nonequilibrated chambers since this in our hands gave a better separation. The plates were sprayed with dichlorofluorescein (Merck), and the spots were scraped off into sintered glass tubes. The phospholipids were eluted with chloroform:methanol:glacial acetic acid: water, $50: 39: 1: 10$, and dichlorofluorescein was extracted by using $4 \mathrm{M} \mathrm{NH} \mathrm{NH}_{4} \mathrm{OH}$ followed by $50 \%$

${ }^{2}$ Otnæss, A.-B. Unpublished observations. methanol in water, as described by Arvidson (19). Phospholipid-phosphorus was determined by the method of Chen et al. (20) after digestion with sulfuric acid. The recovery of phospholipids from the plates was regularly $80-95 \%$.

Platelet aggregation. Platelet aggregation was monitored at $37^{\circ} \mathrm{C}$ with a Payton single-channel aggregometer (Payton Associates Ltd., Scarborough, Ontario, Canada). The platelet response to $\mathrm{ADP}$, thrombin, and collagen was examined before and after treatment with PLC. Final concentrations were $2 \mathrm{mM} \mathrm{CaCl}_{2}, 0.05 \mathrm{NIH} \mathrm{U}$ of thrombin/ml, or $10 \mu \mathrm{M}$ ADP and $0.5 \mathrm{mg} / \mathrm{ml}$ fibrinogen instead of thrombin. The collagen suspension $(2 \mathrm{mg} / \mathrm{ml})$ was prepared as described by Holmsen et al. (21).

$P F-3$. For the purpose of these experiments total PF-3 was operationally defined as the ability of isolated platelets, frozen and thawed three times, to shorten the coagulation time of platelet-poor plasma in the absence of added cephalin. PF-3 was tested in triplicate with the one-stage method of Husom (22) with $0.1 \mathrm{ml}$ activated human plasma plus $0.1 \mathrm{ml}$ test material. Platelet-poor human plasma was activated with $30 \mathrm{mg}$ Celite/ml (Johns-Manville, New York) (22). A standard curve was prepared with dilutions of a suspension of three times frozen and thawed platelets (3.7 $\times 10^{8}$ platelets $/ \mathrm{ml}$ ) as source of PF-3.

$P F-4$. Aliquots of the incubation mixture were centrifuged $\left(12,000 \mathrm{~g} / 10 \mathrm{~min} / 22^{\circ} \mathrm{C}\right)$, and the supernates were frozen before testing by the electroimmunoassay method of Gjesdal (23). Standards of purified PF-4 were included for comparison. Total PF-4 was determined after addition of $2.5 \%$ Triton $\mathrm{X}-100$ and freezing and thawing the platelets once, as well as after freezing and thawing three times. Activity is expressed as units of heparin neutralized.

Serotonin (5HT) efflux. The effect of PLC on 5HT efflux was investigated as described by Lingjærde (24) in separate experiments. PRP with 0.1 vol $3 \%$ (wt/vol) diNa-EDTA as anticoagulant was incubated with $\left[{ }^{14} \mathrm{C}\right]-$ 5HT (Radiochemical Centre, Amersham, U. K., final concn. $0.67 \mathrm{nmol} / \mathrm{ml}$, with sp act $10 \mu \mathrm{Ci} / \mu \mathrm{mol}$ ) in $0.5 \mathrm{vol}$ isotonic sodium phosphate buffer, $\mathrm{pH} 6.4$, for $6 \mathrm{~min}$ at $37^{\circ} \mathrm{C}$, to a total uptake of about $80 \mathrm{pmol}\left[{ }^{14} \mathrm{C}\right] 5 \mathrm{HT} / 10^{8}$ platelets. The platelets were then isolated by centrifugation $(1,000 \mathrm{~g}$ for 12 min at $4^{\circ} \mathrm{C}$ ) and resuspended in $2 \mathrm{vol}$ of the buffer used for gel filtration. 2-ml aliquots were withdrawn, and $50 \mu 1$ PLC $(15 \mu \mathrm{g})$ or $50 \mu \mathrm{l}$ buffer was added. Unlabeled 5HT (final concn. $10 \mu \mathrm{M}$ ) was added to block competitively the uptake of released $\left[{ }^{14} \mathrm{C}\right] 5 \mathrm{HT}$. The samples were incubated at $37^{\circ} \mathrm{C}$ for $10-40 \mathrm{~min}$ and then chilled. Control samples were kept at $4^{\circ} \mathrm{C}$ throughout. No efflux took place at this low temperature for at least $40 \mathrm{~min}$. All samples were centrifuged again $\left(2,500 \mathrm{~g}\right.$ for $15 \mathrm{~min}$ at $\left.4^{\circ} \mathrm{C}\right)$. The supernates were discarded, the test tubes were inverted and drained for $3 \mathrm{~min}$, and the remaining medium was carefully wiped off. Finally, the platelets were lysed in $1 \mathrm{ml}$ distilled water at $37^{\circ} \mathrm{C}$ for $20 \mathrm{~min}$. After a brief centrifugation, $0.6 \mathrm{ml}$ of the supernate was mixed with $6 \mathrm{ml}$ Diluene (Packard Instrument International, Zürich, Switzerland) and counted in a Packard TriCarb liquid scintillation spectrometer (Packard Instrument Co., Downers Grove, Ill.). The control platelets, from which no release had taken place, contained $\left[{ }^{14} \mathrm{C}\right] 5 \mathrm{HT}$ corresponding to about $5,000 \mathrm{cpm}$ in the sample withdrawn for counting. The efflux was expressed as percent loss of platelet-bound $\left[{ }^{14} \mathrm{C}\right] 5 \mathrm{HT}$ during the incubation at $37^{\circ} \mathrm{C}$, compared to the control platelets kept at $4^{\circ} \mathrm{C}$.

Other methods. Analytical disc and sodium dodecyl sulfate polyacrylamide gel electrophoresis were carried out as 
described by Davis (25) and by Laemmli (26). Immunoelectrophoresis was carried out as described by Scheidegger (27) except that $1 \%$ agarose was used. Protein was determined according to Lowry et al. (28). Lactic acid dehydrogenase was determined with the Baker kit (Baker Chemicals, Deventer, Holland) according to Wroblewski and LaDue (29).

\section{RESULTS}

Aggregation measurements. The incubation of PLC with gel-filtered platelets did not cause aggregation either in the absence or in the presence of $1 \mathrm{mM} \mathrm{ZnCl}_{2}$ (final concentration) and did not significantly alter the response of the platelets to thrombin or collagen. In 16 out of 18 experiments the response to ADP was either unchanged or slightly reduced (5-15\%) (Fig. 1). Very similar results were obtained with collagen. No correlation was found between the loss of sensitivity of the platelets to ADP and either the amount of PLC used or the amount of phospholipid hydrolyzed. When SMase $(15 \mu \mathrm{g} / \mathrm{ml})$ was added after incubation of PLC, aggregation occurred within $3-6 \mathrm{~min}$ at $37^{\circ} \mathrm{C}$. The same result was obtained if the platelets were incubated with SMase before PLC, or if the two enzymes were added together. However, SMase alone gave no aggregation. PLC from $C$. perfringens (final concn. $15 \mu \mathrm{g} / \mathrm{ml}$ ) caused aggregation within $1 \mathrm{~min}$ at $37^{\circ} \mathrm{C}$.

PF-3. Total PF-3 decreased markedly after PLC treatment of the platelets. In two experiments the mean decrease was $93 \%$. The corresponding mean increase in coagulation time was from $43.5 \mathrm{~s}$ to $73.5 \mathrm{~s}$.

$P F-4$. The amounts of PF-4 in the supernates from unincubated, PLC-treated, and control incubated platelets were compared (Table I). The total releasable $\mathrm{PF}-4$ is taken as $100 \%$. Incubation with PLC resulted in little or no increase of PF-4 above the amount seen in the supernates from the unincubated and incubated controls. No correlation between amount of PLC added and increase of PF-4 was observed. The experiments showed that PLC did not induce any significant release of PF-4.

Phospholipids. In good accordance with data of others $(30,31)$, the platelets were found to contain $10.0-13.9 \mu \mathrm{g}$ lipid phosphorus $/ 10^{\circ}$ platelets. The composition of the phospholipid fraction is given in Table II. Our data agree reasonably well with data in the literature (31-39). A small amount of phosphatidylinositol was detectable but was not quantified. Control extractions of phospholipids from platelets isolated by centrifugation and washing showed no significant differences from the data in Table II. The phospholipid fraction contained $43.5 \%$ phosphatidylcholine (PC) and $15.8 \%$ SM. The phospholipid content of the platelets was reduced after treatment with PLC, the reduction depending on the amount of PLC added when small amounts of enzyme were used (Fig. 2). The release of lipid phos-

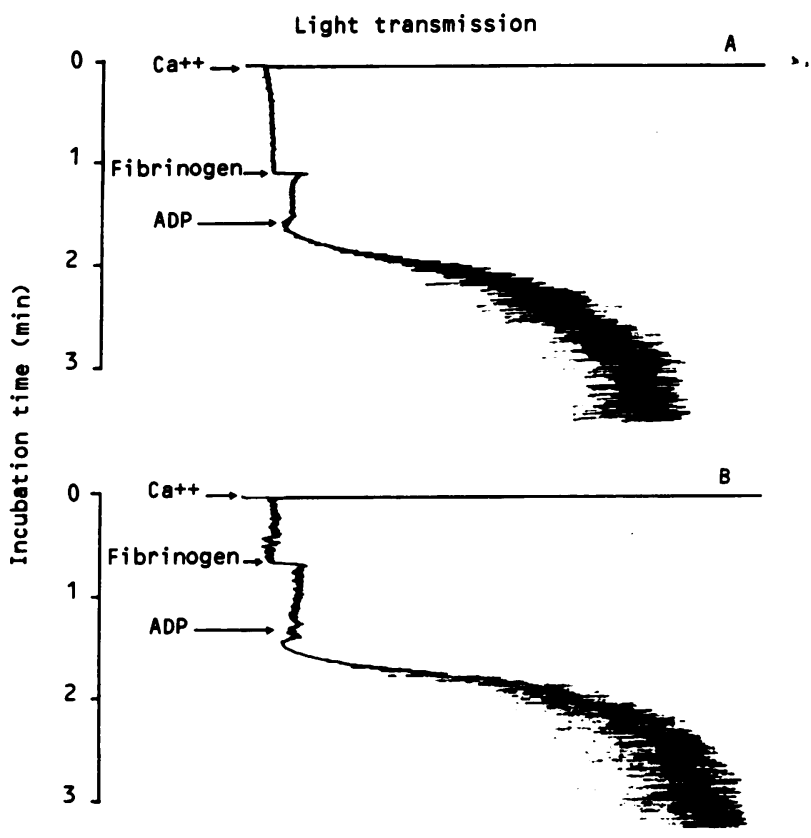

FIGURE 1 Effect of PLC on ADP-induced aggregation of human platelets. $1-\mathrm{ml}$ platelet suspension, $2 \mathrm{mM} \mathrm{CaCl}$, 0.5 $\mathrm{mg} / \mathrm{ml}$ fibrinogen, and $10 \mu \mathrm{M}$ ADP (all final concentrations) were used. (A) After incubation with $26 \mu 1 \mathrm{PLC} / \mathrm{ml}$ (4.3 $\mu \mathrm{g} \mathrm{PLC} / 10^{8}$ platelets) for $20 \mathrm{~min}$ at $37^{\circ} \mathrm{C}$. (B) After incubation with $26 \mu \mathrm{l} / \mathrm{ml}$ Veronal-buffered saline containing $1 \mathrm{mM} \mathrm{ZnCl} 2$ for $20 \mathrm{~min}$ at $37^{\circ} \mathrm{C}$.

phorus from intact platelets reached a plateau value of $30-45 \%$. Essentially no further increase was seen even when 4-10 times more enzyme was used (Fig. 2). On the other hand, when sonicated platelets were incubated with PLC (16.4 $\mu \mathrm{g} \mathrm{PLC} / 10^{8}$ platelets), about $85 \%$ of the total platelet phospholipid was hydrolyzed, indicating that an almost total breakdown of all phospholipids except SM, which is not a substrate, took place when the internal phospholipids were made accessible to the enzyme. There were no significant differences between the phospholipid composition of intact control platelets and

TABLE I

The Effect of Phospholipase C on PF-4

\begin{tabular}{ccccc}
\hline & \multicolumn{4}{c}{ PF-4 activity in supernate from: } \\
\cline { 2 - 5 } $\begin{array}{c}\text { Concn. } \\
\text { of } \\
\text { platelets }\end{array}$ & $\begin{array}{c}\text { Unincubated } \\
\text { platelets }\end{array}$ & $\begin{array}{c}\text { Platelets incubated } \\
\text { with: }\end{array}$ & $\begin{array}{c}\text { Total in } \\
\text { platelets }\end{array}$ \\
\cline { 3 - 5 }$\times 10^{8} / \mathrm{ml}$ & $U /$ liter & $U /$ liter & $U /$ liter & U/liter \\
3.2 & $30(0 \%)$ & $50(3 \%)$ & $83(7 \%)$ & $720(100 \%)$ \\
1.5 & $80(0 \%)$ & $72(0 \%)$ & $90(2 \%)$ & $573(100 \%)$ \\
2.7 & $30(0 \%)$ & $36(1 \%)$ & $42(2 \%)$ & $567(100 \%)$ \\
\hline
\end{tabular}

PF-4 was measured in the supernate after removal of platelets by centrifugation $\left(12,000 \mathrm{~g} / 10 \mathrm{~min}\right.$ per $\left.20^{\circ} \mathrm{C}\right)$. PF-4 activity in supernates from unincubated platelets was subtracted as background. 
TABLE II

Phospholipid Composition of Gel-Filtered Platelets*

\begin{tabular}{cc}
\hline & Percent of total \\
\hline & $\%$ \\
SM & $18.1(14.7-21.5)$ \\
PC & $46.2(43.8-48.0)$ \\
PS & $11.0(7.7-14.6)$ \\
PE & $23.9(21.7-28.3)$
\end{tabular}

Phospholipids were separated by thin-layer chromatography, the spots scraped off, eluted with chloroform/methanol/ glacial acetic acid/water and digested, and phosphate was determined (see Methods).

* Mean and range of six experiments.

that of sonicated control platelets, indicating that no endogenous phospholipase activity appeared in the platelets after sonication. In the intact platelets, only about $40 \%$ of the total phospholipid was hydrolyzed, with the different phospholipids being hydrolyzed to differing extents (Fig. 3). Phosphatidylethanolamine (PE) was the most susceptible to hydrolysis $(50-75 \%)$, followed by PC $(20-50 \%)$ and phosphatidylserine (PS) $(20 \%)$, while SM was not attacked. The amount of SM recovered after PLC treatment appeared to increase $5-10 \%$. The hydrolyses of the individual phospholipids reached a plateau value that was not further increased

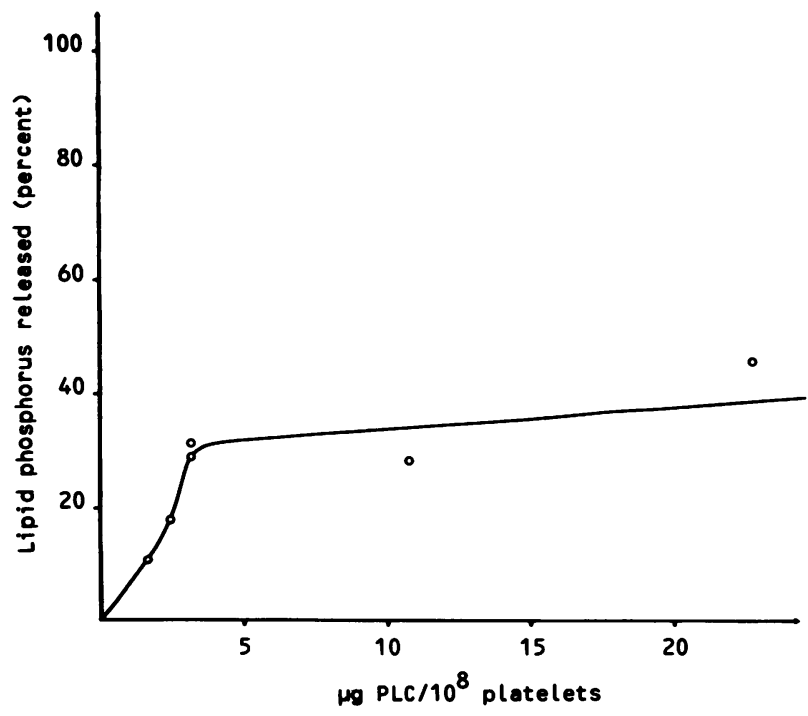

FIgURE 2 Effect of PLC on the total phospholipid content of intact platelets. The platelet suspensions were centrifuged after incubation with PLC or buffer. Lipid was extracted with chloroform/methanol and phosphate determined after digestion. by increasing amounts of enzyme (Fig. 3). With SMase only $20-25 \%$ of the total platelet $\mathrm{SM}$ was hydrolyzed.

Efflux of serotonin. Monitoring the efflux of $\left[{ }^{14} \mathrm{C}\right]-$ $5 \mathrm{HT}$ from preloaded platelets showed that incubation with PLC did not trigger any release of $5 \mathrm{HT}$. The efflux curve (Fig. 4) showed the same slow efflux as seen with the preloaded control platelets. The only difference was that with the PLC-treated platelets the efflux was reproducibly about $3 \%$ higher at all time points.

Lactic acid dehydrogenase. $3.7 \times 10^{8}$ platelets were incubated for $20 \mathrm{~min}$ at $37^{\circ} \mathrm{C}$ with $19 \mu \mathrm{g}$ PLC. No release of lactic acid dehydrogenase (EC 1.1.1.27) from the platelets to the supernate was observed.

\section{DISCUSSION}

The present study demonstrates that gel-filtered human platelets may lose up to at least $45 \%$ of their total phospholipid without induction of aggregation, or release or significant impairment of their response to ADP, thrombin, or collagen. The platelets fully retained their sensitivity and response to thrombin. The response to ADP was slightly reduced in most experiments, but the decrease did not correlate with the amount of phospholipid hydrolyzed and was therefore probably not related to the enzymatic activity. The response to collagen showed variations similar to those of the ADP response. These findings are in apparent contrast to the results of Schick and $\mathrm{Yu}(1)$, who found that crude PLC ( $C$. perfringens) induced a release reaction when only a small amount $(5-10 \%)$ of the phospholipid had been hydrolyzed. The corresponding loss of $\mathrm{PC}$ was $25 \%$ and of SM 9\%. Chap and Douste-Blazy (2) reported essentially similar experiments with a similar preparation of PLC ( $C$. perfringens) and obtained basically the same results.

We confirm their results with regard to the ability of the $C$. perfringens enzyme to aggregate platelets. Both PC and SM are good substrates for this enzyme (40), whereas the Bacillus enzyme did not hydrolyze SM under the present reaction conditions. An extensive hydrolysis by the Bacillus enzyme of $\mathrm{PE}$ (up to 60$75 \%$ ), of PC (about $50 \%$ ), and of PS (20\%) was not enough to induce platelet aggregation or release. Aggregation was observed only when gel-filtered platelets were treated with the Clostridium enzyme or with SMase and the Bacillus enzyme in combination or in sequence. This clearly demonstrates that even when extensive hydrolysis of the other phospholipids occurs, some SM (about 20-25\%) must be hydrolyzed for aggregation and release to take place. When a certain degradation of the other phospholipids has taken place, this small degree of hydrolysis of SM $(3.5-4.5 \%$ of the total platelet phospholipid) apparently determines 
whether the platelets remain intact or aggregate. Hydrolysis of SM alone is, however, not sufficient to induce aggregation. These findings are comparable to those of Colley et al. (41), obtained with erythrocytes, except that the erythrocyte phospholipids were not accessible to PLC unless the erythrocytes were exposed to SMase before PLC.

No evidence for induction of a release reaction by incubation with PLC was found. Less than 4\% of total releasable PF-4 was released during the PLC treatment if the release from the incubated control platelets was subtracted as background. It has been suggested (42) that about $10 \%$ of PF-4 is bound to the plasma membrane. The $2-4 \%$ released by PLC may derive from this fraction.

The efflux of $\left[{ }^{14} \mathrm{C}\right] 5 \mathrm{HT}$ from preloaded platelets also showed only a very slight increase $(3 \%)$ in the presence of PLC, in contrast to the situation when a release reaction takes place and about $70-85 \%$ of total platelet $5 \mathrm{HT}$ appears in the supernate in less than $40 \mathrm{~s}$ (43). The parallel course of the efflux curves (Fig. 4) suggests that there was probably no difference in the efflux from the main intracellular pool of 5HT in the PLCtreated and in the control platelets. The small constant $3 \%$ difference remains unexplained, but may possibly be due to loss of a small plasma membrane-bound fraction of $5 \mathrm{HT}$. In conclusion, both the PF-4 and the $\left[{ }^{14} \mathrm{C}\right] 5 \mathrm{HT}$ determinations indicate that no release reaction is induced by the Bacillus enzyme.

The loss of phospholipids reached a plateau of $30-45 \%$ when intact platelets were exposed to PLC and this loss

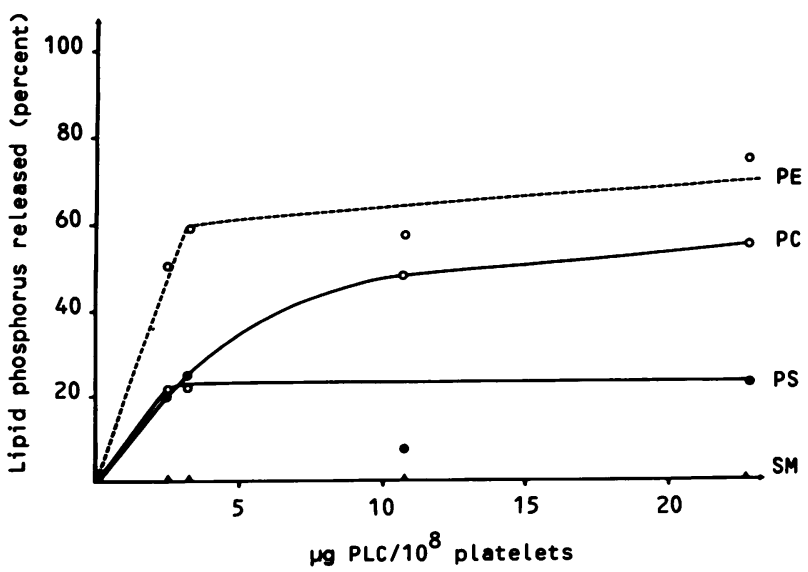

Figure 3 Effect of phospholipase $\mathrm{C}$ on phospholipids in platelets. Platelet suspension was centrifuged after incubation with PLC or buffer. Lipid was extracted with chloroform $/$ methanol. The phospholipids were separated by thinlayer chromatography, the individual spots were scraped off and eluted and phosphate was determined after digestion.

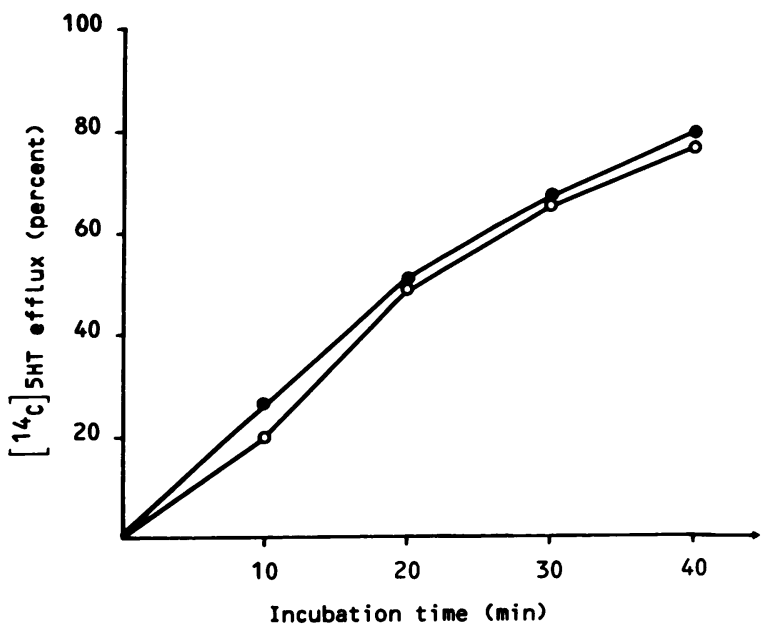

Figure 4 Efflux of $\left[{ }^{14} \mathrm{C}\right] 5 \mathrm{HT}$ from preloaded platelets in the presence $(\bullet)$ and absence $(O)$ of phospholipase $\mathrm{C}$. Efflux is given as loss of platelet-bound $\left[{ }^{14} \mathrm{C}\right] 5 \mathrm{HT}$ during incubation at $37^{\circ} \mathrm{C}$, in percent of controls kept in ice-cold water. Each point represents the mean of three samples.

was not increased further by increasing the amount of enzyme. A similar figure was found when platelets isolated by centrifugation and washing were used. The hydrolysis of the various phospholipids also reached different plateau levels (Fig. 3), whereas in platelet sonicates the phospholipids were completely hydrolyzed by the same amounts of enzyme. Taken together with the absence of release of PF-4 and 5HT and the lack of lactic acid dehydrogenase leakage from the platelets, these findings strongly suggest that only the phospholipids of the outer layers of the platelet membrane (except SM) are accessible to the enzyme and that the PLC attack was limited to the outside of the membrane. This is in accordance with observations in other systems $(41,44)$. If PLC hydrolyzes only the outer layer phospholipids, then the distribution of phospholipids in the platelet membrane may be calculated (Fig. 5), provided that the following assumptions are made: $(a)$ the accessible membranes (plasma membrane and main surface-connecting channels) account for about two-thirds of the total phospholipids of platelets; $(b)$ the phospholipid compositions of accessible and internal membranes are not grossly different $(32)$; and (c) the inner and outer layers of the plasma membranes have about the same protein-to-phospholipid ratio. (This latter assumption may not be strictly correct, since it has been suggested that the inner layer contains more protein than the outer (44).

Since $60-70 \%$ of $\mathrm{PE}$ is hydrolyzable, the remaining $30-40 \%$ is either part of the inner layer of the plasma membrane or of the intracellular membranes. SMase 


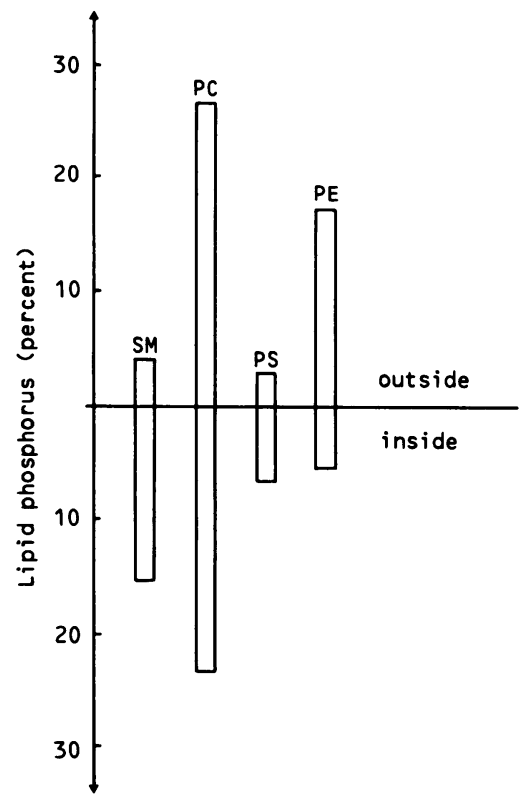

FIGURE 5 Estimated phospholipid composition of inner and outer layer of the platelet plasma membrane.

hydrolyzed $20-25 \%$ of SM. From the same reasoning, this fraction must be located in the external membrane to be available to the enzyme. The estimate of phospholipid distribution (Fig. 5) based on these assumptions and considerations is obviously not accurate in detail, but demonstrates the asymmetry in the platelet plasma membrane. The main difference from results obtained with other membranes $(41,44,45)$ is that more $\mathrm{PE}$ seems to be located to the outer plasma membrane layer in the platelets. This feature may be related to the special origin of platelets and correlates nicely with the well-known procoagulant activity of $\mathrm{PE}$ and $\mathrm{PS}+\mathrm{PE}$, thought to be responsible for the PF-3 activity (46).

$\mathrm{PF}-3$ as defined here is generally assumed to be partly localized in the plasma membrane (available PF-3) and partly in the interior of the platelet, being made available during the release reaction. The decrease in total PF-3 activity after PLC treatment must mean that the main part of the structures carrying the PF-3 activity are accessible to PLC, i.e. if our interpretation of the present data is correct, they are localized in the plasma membrane. The exact nature of these structures is currently unknown, although Vecchione and Zucker (47) recently have produced evidence that phospholipids alone can substitute completely for platelets in a plasma recalcification system.

\section{ACKNOWLEDGMENTS}

The kind help of Professor O. Lingjærde and Dr. K. Gjesdal is gratefully acknowledged. Dr. R. Möllby kindly donated samples of SMase from Staphylococcus aureus and
PLC from Clostridium perfringens. T. Kirker $\varnothing \mathrm{d}$ provided technical assistance.

\section{REFERENCES}

1. Schick, P. K., and B. P. Yu. 1974. The role of platelet membrane phospholipids in the platelet release reaction. J. Clin. Invest. 54 : 1032-1039.

2. Chap, H., and L. Douste-Blazy. 1974. Reaction de liberation plaquettaire induite par la phospholipase $C$. Eur. J. Biochem. 48: 351-355.

3. Möllby, R., and T. Wadstr $\varnothing \mathrm{m}$. 1973. Purification of phospholipase C (alpha-toxin) from Clostridium perfringens. Biochim. Biophys. Acta. 321: 569-584.

4. Wadstr $\varnothing \mathrm{m}$, T., and R. Möllby. 1971. Studies on extracellular proteins from Staphylococcus aureus. VI. Production and purification of beta-haemolysin in large scale. Biochim. Biophys. Acta. 242: 288-307.

5. Wadstr $\not \mathrm{m}, \mathrm{T}$., and R. Möllby. 1971. Studies on extracellular proteins from Staphylococcus aureus. VII. Studies on beta-haemolysin. Biochim. Biophys. Acta. 242: 308-320.

6. Möllby, R., and T. Wadstr $\phi \mathrm{m}$. 1973. Purification of staphylococcal beta-, gamma- and delta-haemolysins. In Staphylococci and Staphylococcal Infections. J. Jeljaszewicz, editor. Karger Press, AG, Basel. 298-313.

7. Aster, R. H., and J. H. Jandl. 1964. Platelet sequestration in man. I. Methods. J. Clin. Invest. 43: 843-855.

8. Østerud, B., T. Holm, and H. Prydz. 1974. The effect of factor IX and factor X on blood platelets. Scand. J. Haematol. 13 : 161-165.

9. Tangen, O., and H. J. Berman. 1972. Gel filtration of blood platelets: a methodological report. In Platelet function and thrombosis. P. M. Mannucci and S. Gorini, editors. Plenum Press, New York. 235-243.

10. Mustard, J. F., D. W. Perry, N. G. Ardlie, and M. A Packham. 1972. Preparation of suspensions of washed platelets from humans. Br. J. Haematol. 22: 193-204.

11. Otnæss, A-B., C. Little, and H. Prydz. 1974. The synthesis of phospholipase $\mathrm{C}$ by Bacillus cereus. II. A screening method for mutants. Acta Pathol. Microbiol. Scand. Sect. B Microbiol. Immunol. 82: 354-356.

12. Little, C., B. Aurebekk, and A-B. Otnæss. 1975. Purification by affinity chromatography of phospholipase $C$ from Bacillus cereus. FEBS (Fed. Eur. Biochem. Soc.) Lett. 52: 175-179.

13. Hjort, P. F. 1957. Intermediate reactions in the coagulation of blood with tissue thromboplastin. Scand. J. Clin. Lab. Invest. Suppl. 9 (Suppl. 27). 183 pp.

14. Vikrot, O. 1964. Quantitative determination of plasma phospholipids in pregnant and non-pregnant women, with special reference to lysolecithin. Acta Med. Scand. 175: 443-453.

15. Nord $\varnothing y$, A., E. Str $\varnothing \mathrm{m}$, and K. Gjesdal. 1974. The effect of alimentary hyperlipaemia and primary hypertriglyceridaemia on platelets in man. Scand. J. Hacmatol. 12: 329-340.

16. Folch, J., M. Lees, and G. H. Sloane Stanley. 1957. A simple method for the isolation and purification of total lipids from animal tissues. J. Biol. Chem. 226: 497-509.

17. Marcus, A. J., L. B. Safier, and H. L. Ullman. 1972. The lipids of human platelets. In Blood Lipids and Lipoproteins. John Wiley \& Sons, Inc., New York. 417-439.

18. Stahl, W. L. 1973. Phospholipase C purification and specificity with respect to individual phospholipids and 
brain microsomal membrane phospholipids. Arch. Biochem. Biophy's. $154:$ 47-55.

19. Arvidson, G. A. E. 1968. Structural and metabolic heterogeneity of rat liver glycerophosphatides. Eur. J. Biochem. $4:$ : 478-486.

20. Chen, P. S. Jr., T. Y. Toribara, and H. Warner. 1956 Microdetermination of phosphorus. Anal. Chem. 28: 1756-1758.

21. Holmsen, H., H. J. Day, and E. Storm. 1969. Adenine nucleotide metabolism of blood platelets. VI. Subcellular localization of nucleotide pools with different functions in the platelet release reaction. Biochim. Biophys. Acta. 186: 254-266.

22. Husom, O. 1961. A one stage method for the assay of platelet factor 3. Scand. J. Clin. Lab. Invest. 13: 609618.

23. Gjesdal, K. 1974. Platelet factor $4(\mathrm{PF}-4)$. An electroimmuno assay for PF-4 in human plasma. Scand. J. Hacmatol. 13: 232-240.

24. Lingjærde, O. Jr. 1970. Effects of ergotamine and dihydroergotamine on uptake of 5-hydroxytryptamine in blood platelets. Eur. J. Pharmacol. 13: 76-82.

25. Davis, B. J. 1964. Disc electrophoresis II. Method and application to human serum proteins. Ann. N. Y. Acad. Sci. 121: 404-427.

26. Laemmli, U. K. 1970. Cleavage of structural proteins during the assembly of the head of bacteriophage T4. Nature (Lond.). 227: 680-685.

27. Scheidegger, J. J. 1955. Une micro-methode de l'immunoelectrophorese. Int. Arch. Allergy Appl. Immunol. 7: 103-110.

28. Lowry, O. H., N. J. Rosebrough, A. L. Farr, and R. J. Randall. 1951. Protein measurements with the folin phenol reagent. J. Biol. Chem. 193: 265-275.

29. Wroblewski, F., and J. S. LaDue. 1955. Lactic dehydrogenase activity in blood. Proc. Soc. Exp. Biol. Med. 90: 210-213.

30. Nord $\varnothing y$, A., K. Gjesdal, S. Jæger, and H. Berntsen. 1975. The effect of noradrenalin infusion on plasma and platelet lipids and platelet function in man. Thromb. Diath. Haemorrh. 33: 328-334.

31. Lewis, N., and P. W. Majerus. 1969. Lipid metabolism in human platelets II. J. Clin. Invest. 48: 2114-2123.

32. Marcus, A. J., H. L. Ullman, and L. B. Safier. 1969. Lipid composition of subcellular particles of human blood platelets. J. Lipid Res. 10: 108-114.

33. Blomstrand, R., F. Nakayama, and I. M. Nilsson. 1962. Identification of phospholipids in human thrombocytes and erythrocytes. J. Lab. Clin. Med. 59: 771-778.

34. Cohen, P., A. Derksen, and H. van den Bosch. 1970.
Pathways of fatty acid metabolism in human platelets. J. Clin. Invest. 49: 128-139.

35. Troup, S. B., C. F. Reed, G. V. Marinetti, and S. N. Swisher. 1960. Thromboplastic factors in platelets and red blood cells: observations on their chemical nature and function in in vitro coagulation. J. Clin. Invest. 39: 342-351.

36. Nord $\phi y, A$., and S. Lund. 1968. Platelet factor 3 activity, platelet phospholipids and their fatty acid and aldehyde pattern in normal male subjects. Scand. $J$. Clin. Lab. Invest. 22: 328-338.

37. Cohen, P., and A. Derksen. 1969. Comparison of phospholipid and fatty acid composition of human erythrocytes and platelets. Br. J. Haematol. 17: 359-371.

38. Boggust, W. A. 1972. Platelet lipids and coagulation in plasma. I. Isolation and analysis. Ir. J. Med. Sci. 141: 128-135.

39. Safrit, H. F., H. J. Weiss, and G. B. Phillips. 1972. The phospholipids and fatty acid composition of platelets in patients with primary defects of platelet function. Lipids. 7: 60-67.

40. Sugahara, T., and A. Ohsaka. 1970. Two molecular forms of Clostridium perfringens $\alpha$-toxin associated with lethal, hemolytic and enzymatic activities. Jpn.J. Med. Sci. Biol. 23: 61-66.

41. Colley, C. M., R. F. A. Zwaal, B. Roelofsen, and L. L. M. Van Deenen. 1973. Lytic and non-lytic degradation of phospholipids in mammalian erythrocytes by pure phospholipases. Biochim. Biophys. Acta. 307: 74-82.

42. Moore, S., D. S. Pepper, and J. D. Cash. 1975. Platelet antiheparin activity. The isolation and characterization of platelet factor 4 released from thrombin-aggregated washed human platelets and its dissociation into subunits and the isolation of membrane-bound antiheparin activity. Biochim. Biophy's. Acta. 379: 370-384.

43. Holmsen, H., H. J. Day, and H. Stormorken. 1969. The blood platelet release reaction. Scand. J. Haematol. Suppl. 8.

44. Tasi, K-H., and J. Lenard. 1975. Asymmetry of influenza virus membrane bilayer demonstrated with phospholipase C. Nature (Lond.). 253: 554-555.

45. Bretscher, M. 1972. Asymmetrical lipid bilayer structure for biological membranes. Nat. New Biol. 236: 1112.

46. Gautheron, P., E. Dumont, and S. Renaud. 1974. Clotting activity of platelet phospholipids in rat and man. Thromb. Diath. Haemorrh. 32: 382-390.

47. Vecchione, J., and M. B. Zucker. 1975. Procoagulant activity of platelets in recalcified plasma. Br. J. Haematol. 31: 423-428. 